INTERNATIONAL JOURNAL OF MULTIDISCIPLINARY RESEARCh AND ANALysis

ISSN(print): 2643-9840, ISSN(online): 2643-9875

Volume 04 Issue 06 June 2021

DOI: 10.47191/ijmra/v4-i6-06, Impact Factor: 6.072

Page No.- $720-725$

\title{
LGBTQ (Lesbian, Gay, Bisexual, Transgender and Queer) and the Question of Holistic Human Life Development: Issues and Perspectives
}

\author{
Hilary Elochukwu Anaelom ${ }^{1}$, Ignatius Nnaemeka Onwuatuegwu PhD ${ }^{2}$ \\ ${ }^{1}$ Holy Family Fathers and Brothers of the Youth Novitiate Okija, Anambra State, Nigeria \\ ${ }^{2}$ Department of Philosophy, Faculty of Arts Nnamdi Azikiwe University Awka, Nigeria
}

\begin{abstract}
Sexuality is a fundamental component of human personal existence. Human sexuality as an aspect of human existence in the world involves a variety of dimensions, in dealing with these dimensions of human sexuality, this paper adopts a favored option regarding the multi-disciplinary procedural framework. In the context of the multidisciplinary procedural framework this paper pays attention to the question of terminology and theories in relation to the origins of homosexuality, health and disease categories, together with the holistic Development of human life viz-a-viz issues and perspectives. In the polarized arena of public and social discourse, with a cacophony of voices calling for or against the legal institutionalization of "gay marriage," it is also important to call attention to the imperative of responsibility as an overarching ethical imperative. However, this papers overall goals are to stimulate thought by disrupting the present paradigm of counseling psychology as a primarily ameliorative endeavor, and to replace professional rhetoric regarding prevention and advocacy with concrete recommendations informed by pastoral doctrinal theory and research.
\end{abstract}

KEYWORDS: Lesbian, Gay, Bisexual, Transgender, Queer, Human Sexuality.

\section{0 INTRODUCTION}

The human person is a complex unity and within the context of this complex unity, human sexuality remains a complex phenomenon. Scholars from diverse perspectives have made efforts in the attempt to offer explanations with regard to the phenomenon of homosexuality. But up till the present period, the current level of human knowledge has not been able to offer a universally acceptable scientific explanation with regard to the question of homosexuality. However, LGBT issues has over the past years in the global politics and sociological knowledge has become a matter of great concern, following the framework of reflexive modernity,[1] one can categorically assert at this juncture that grassroots and social movement are of paramount importance in the social transformation attained by LGBT politics. State-sponsored Homophobia report published by the International Lesbian, Gay, Bisexual, Trans and Intersex Association (ILGA) confirmed in 2017 that homosexual activities is still illegal in seventy-one countries and punishable by death in thirteen countries worldwide.[2]

However, one must not be induced to think that LGBTQ is relatively rare because one does not come across if often in the confessional or the parlour. Owning to the stigma, which society has placed upon the homosexual, the latter shies away from revealing his tendencies to people of normal sexual constitution ${ }^{1}$ but it should be understood that not all persons with a homosexual constitution also engage in active homosexual practices. Thus, the insight derived from the understanding of the complex nature of human existence, points to the fact that human sexuality is replete with complexities, for the sake of brevity this work will pay attention only to a few of these, and, in a lapidary manner.

This paper pays attention to the question of terminology and theories in relation to the origins of homosexuality, health and disease categories, together with the holistic Development of human life viz-a-viz issues and perpectives.

2.0 CONCEPTUAL CLARIFICATIONS: MEANING AND HISTORY OF LGBTQ (the historical trajectory of LGBTQ)

Lesbian, gay, bisexual, transgender and Queer (LGBTQ), emanated from the word "gay community," this however first came into the picture in the 50s and 60s, and later proponents added the alphabet GLB to also mean lesbian and bisexual people, because they thought Gay wasn't in itself all-encompassing of other identities.[3] 

Issues and Perspectives

Nevertheless, the idea of having a distinctive sexual identity was not invoke before the late-nineteenth century, not minding that lives where lived in the past similar to what we have now and perceived to be LGBTQ. Gay identity, not until the mid-twentieth century, personal and political category was still undiscovered. It is worthy to note here that the clarity that is invoke today in $x-$ raying sexuality and gender never existed in the historical vocabulary

The word lesbian has its root from the Greek island of Lesbos, which the poet Sappho is connected with, not minding that her surviving writing lyrically describes erotic love and attraction between women. Notwithstanding that "gay" is used as an allencompassing word for gender and sexual minorities, and with the import of Women's Movement (which is also known as the U.S. feminist movement, the second wave) however, gay women in an attempt to strike a balance articulated the mid-to-late twentieth-century how their experiences differed from the heterosexual women that formed the majority of the movement.

"Gay" are men who are homosexuals, or simply put, as a man who is sexually attracted to other men. This however surfaced in the early twentieth century as ban underground word and brought to limelight in the 1960s. Stonewall generation though contrary to their predecessor viewed gay as not being a deficiency. the current assertion of gay in our contemporary world today boils down to men who are sexually attracted to each other, documentary made us to understand that it was recycled as an extensive word to incorporate the totality of the contemporary understanding of LGBT acronym. In reference to their liberation as street queens of color, in the 1970s, activists Sylvia Rivera and Marsha P. Johnson often spoke of "gay rights" or "gay power" (who nowadays would be referred to as transgender).

Although, the whole range of sexual and gender minorities in the 1990s where referred to "gay". With the escalation of bisexual, transgender, and questioning the application shifted, giving rise to LGBTQ which they believe was more encompassing than just "gay"

Transgender: in order to form alliance of persons that did not practically suit into gender binaries or those outside gender norms transgender was initiated and championed by Kate Bornstein, Holly Boswell, Leslie Feinberg, and Riki Wilchins. Some Transsexuals often prefer transgender because of its association with medical transitions.

Bisexual: this is often used to denote human attraction be it sexual or romantic feelings towards men and, [4] it is however on of the three categories of sexuality bearing in mind homosexual and heterosexual which could also be referred to as heterosexual-homosexual gamut, thus, those with clear but not complete predilection for one sex above the other equally classify themselves to be bisexual.[5]

The letter " $Q$ " which means "queer" or those who are still "questioning" their gender identity or orientations was brought into the picture in the later century. "Queer" simply means retrieved identity (which means literally "odd" or "quaint," it was fundamentally a word used derogatorily for gays), it therefore showcases a more aggressive approach as a comprehensive word that shrouded anyone or thing outside the family of gender and sexual orientations.

\subsection{HOMOSEXUALITY: THE QUESTION OF HUMAN LIFE DEVELOPMENT}

The definite biotic composition that determines the development of human beings as lesbian, gay, bisexual, transgender, queer or questioning still remains a topic of discussion, but suffice it to say that scholars have resolutely maintains that neither the human person is of affectional orientation nor gender identity is a choice. Like the human colour, they are unalterable fragments of the real essence of a person, thus they are inborn

The important questions remain: What are the origins of homosexuality? Is homosexuality a product of genetic-biological factors or psycho-social factors? Or, is homosexuality an interaction of genetic-biological factors and psycho-social factors? In the attempt towards a profound intellectual encounter with these questions, we will examine some of the experiential theoretical explanations that have been proffered.

\subsection{Homosexuality: The Question of Experiential Theories:}

The American Psychological Association's brochure Sexual Orientation \& Homosexuality of 2008 asserts, "There is no consensus among scientists about the exact reasons that an individual develops a heterosexual, bisexual, gay, or lesbian orientation. Although much research has examined the possible genetic, hormonal, developmental, social, and cultural influences on sexual orientation, no findings have emerged that permit scientists to conclude that any specific dynamic or dynamics determines someone's sexual orientation

Although we cannot outplay the complex roles that nature and nurture plays, for some persons has no less of a choice in the course of their sexual composition. Thus, there are four major perspectives with regard to experiential theories of homosexuality. 
LGBTQ (Lesbian, Gay, Bisexual, Transgender and Queer) and the Question of Holistic Human Life Development: Issues and Perspectives

\subsubsection{Early Sexual Experiences Theory}

This focuses on the initial (early) sexual experiences of the person, and went further to argue that through the process of Skinner operant conditioning along the lines of Pavlovian classical conditioning model, same sex attraction arises as a result of an early pleasurable experience. Thus, this theory has in a way given us the foundation for the seduction and first encounter philosophies of homosexuality, which asserts that individuals are incorporated into homosexual family or regime

\subsubsection{Family Dynamics Theory}

A further experientialist focus is on the importance of family dynamics. The Triangular system that is characterized by a close binding (domineering-seductive) mother and a distant father has been the most recommended psychoanalytic hypothesis controlling exploration about parental impacts on male homosexuality. On the basis of the above the mother relationship was universally well-thought-out as been the root cause.

This "seductive mother" hypothesis, influences their sexual orientation because their mothers had acted like girlfriends or lovers with them

However, the pivotal argument of this theory tends from the angle that strong mother's impact and absence of the father gives rise to male homosexuality. This hypothesis has served as a template for many society's typecasts on the development of homosexuality, together with the physiognomies of homosexuals and the family members.

\subsubsection{Gender Roles in Early Childhood Theory}

The gender roles of early childhood, provides a further area of interest. Within the context of this theory it is assumed that gender-atypical children like girls who are "tomboys" and boys who are "sissy boys" develop into homosexuals. [6]

\subsubsection{Potential Role of Biology Theory}

Potential role of biology theory serve as cryptographs for childhood personality types and temperaments, and are thus shaped into gender roles. However, immediately gender roles are developed my children, those who are exceptional would be seen as been "exotic" and "the other". Girls who fit masculine gender roles will develop to lesbians and girls who fit feminine gender roles into heterosexual women. [7] Although, there are some controversies surrounding these theories and as such some of these theories are not generally acceptable.

However, In the face of these controversies and cacophony of voices, it is important to note that, there could be situations in which there may be a conflict between the gender that is assigned at birth, and the gender identity that a person has of hims elf or herself, a conflict between the birth-defined gender and self-identified gender, which leads to the emergence of further questions with regard to the problem of transgenderism. However, the question still remains: when there is a conflict between biological gender and psychological self-identity, should the mind be transformed to conform to the body, emphasis on the psyche, or should the body be restructured to conform to the mind, emphasis on Sex Reassignment Surgery? What constitutes the concept of the "self" and "self-identity"? These questions are open to philosophical, religious, cultural, and scientific debates.

\subsection{Homosexuality: The Question of Health and Disease Categories}

The question of homosexuality in relation to the health and disease categories, has always have a lot of controversies, and it is important to address some of these issues. In 1952, in the first edition of its monumental classification of diseases, the American Psychiatric Association, APA, categorized homosexuality as a "sociopathic personality disorder." In 1968, it described homosexuality as a "personality disorder." More so, the third edition of the Diagnostic and Statistical Manual of Mental Disorders, 1980, American Psychiatric Association viewd homosexuality as an "ego-dystonic disorder." In 2000, the Text Revision of American Psychiatric Association, Diagnostic and Statistical Manual of Mental Disorders, Fourth Edition, quietly eliminated such classification. [8] Here the question arises, what is at the basis of these changes in the classification of homosexuality? Is it as a result of new scientific knowledge? Even in situations where one admits of new scientific knowledge as the reason, it should never be forgotten, that scientific knowledge is carried out within historical, social, economic, political and cultural context, and these contexts, influence perceptions and judgements. However it is axiomatic in medicine that health is the absence of disease, the concept of health should be analyzed in relation to empirical knowledge and physiological operation of the organism. Nevertheless, due to its intrusion with reproduction homosexuality could be thus categorized as a disease.

\subsection{HOMOSEXUALITY (LGBTQ): ISSUES AND PERSPECTIVES}

\subsection{Issues Associated With Lgbtq Communities}

It is important to consider LGBTQ communities with regard to the many challenges they encounter, such that making sincere effort to offer them some sense of acceptance becomes a lead way to giving them the assurance of the best way to live. 
LGBT persons face considerable levels of stigmatization, discrimination and harassment in the society. Sequel to this, some end up becoming addicted to drinking, eating, drug use and even attempt suicide. Often they are subjected to verbal as well as physical abuse by people around them because of lack of understanding and acceptance.

In many cases they are abandoned, leaving a good number of them in difficult conditions who may practically end up falling prey to anxiety, depression, psychological depression and poor mental health in general. With the resounding voices of male couples in an attempt to build and have families of their own, there has been a yearning for them to become parents together and as such working tirelessly in establishing an orthodox family structure within their relationships.

Although with respect to the deep-rooted typecasts, social acceptance of homosexuality is far from universal and will still remain a nightmare

\subsection{Evaluating the Implications of Lgbtq Movement}

We must understand that within the animal class homosexuality refers to same sex attraction. Although, with respect to higher animals, an obvious demarcation was made of by nature on the area of male and female partners, one must bear in mind that one of the real essence of human existence is the attempt to continue with the procreative work of God so as to guarantee the continuity of human race. On the basis of the above animal behaviour is primarily directed toward the maintenance of the gene pool.

Therefore, in an attempt to accepting homosexuality, one will like to think twice and thus evaluate both the remote and proximate implications of homosexuality, some of which tends from the traditional form of marriage, the mental development of a child raised with LGBTQ orientations, we cannot forget the implications from social interaction, implications for the genealogical continuity of human race and finally its implications for authentic Christian witnessing.

With respect to the above, the orthodox belief of male and female spouses and consequent marriage is directly challenged by homosexual interactions. With this many communities still finds it very difficult and thus considers it to be irrational and a taboo.

Despite the fact that gay couples are as a matter of fact advocating inclusiveness in an "orthodox family structure" [9] within their relationship, it is pertinent to underscore this juncture the impact of the man in the psychological development of the children. There exist a variety of roles the fathers play in a child lives not necessarily as a provider or one who instill order but as moral teacher and role models

One will unanimously be made to believe that homosexual children because of circumstances are always stigmatized and not losing the sight that homosexual fathers most likely produces homosexuals and recognizing the fact that their own children might be victims

Nonetheless, how then do we bear witness to this mandate "Go be fruitful and multiply" if we make homosexuality a universal endeavour, if we say Yes to adoption, the question is, whose child are they going to adopt or are we giving way to assisted reproductive technology (ART)? Not minding the fact millions of children has been raised by gay couples probably through various kinds of means. The church in an attempt to proffer a lasting solution asserts that marriage is strictly reserved for heterosexual couples so as to not thwart the beauty and the ends of marriage. Simply put; every marriage gears towards procreation.

Although, there are vast differences in views with respect to homosexuality: with the fact that it has been in the front burner of every deliberation and as such generally considered as illegal and unacceptable

\subsection{Theological / Pastoral Care for Lgbtq Persons}

The Church through various means official or unofficial medium as a mother has offers pastoral care for LGBTQ persons, though may differ from one diocese to another though not without some struggles. I will be too quick to maintain at this point that the desire to will of God our Father which is the Catholic moral standpoint is root on human reason and thus illumined by faith

The Church as a mother in an attempt to offer solution regardless that they use of some scientific data transcends the realm of science in order to bring to accomplishment the rich reality of human person bearing in mind both the spiritual and physical dimensions of human existence.

However, we need not to be reminded that in the Catholic sphere the issue of homosexuality together with its evaluation with respect to right and wrong has become a case of public debate and dialogue. This however, has caused a lot of incoherency and thus, triggers arguments that punctures the real doctrine of the Catholic Church, it thus, poses a lot of threat and calls for concern and orthodoxy to those entrusted with pastoral ministry 

Issues and Perspectives

Homosexuality from documentation, complex and complicated though it is, both socially and ecclesiastically should be the emphasis for the Church in Her pastoral care as a mother. Her ministers within this context as a matter of urgency should equipped themselves and engage in an active honest well balanced theological counsel. [10]

In responding to guy rights by the church in the late $20^{\text {th }}$ century still condemns homosexual acts although upholding the existence of gay and therefore advocates for love, respect and care for homosexuals. The Congregation of the Doctrine of the Faith under Pope Paul VI In January 1976, published Persona Humana, in an attempt to codify the teaching against all extra-marital sex, including gay sex. This document affirmed in the very first article that: "According to contemporary scientific research, the human person is so profoundly affected by sexuality that it must be considered as one of the factors which give to each individual's life the principal traits that distinguish it." [11] The declaration on certain problems of sexual Ethics (Persona Humana) of the congregation for the Doctrine of Faith of 1975 explains that confirmed homosexuals should be treated with understanding and their culpability judged with prudence, and a letter to the Catholic bishops of 1986 by the same Congregation confirms this judgment once again, [12] to the extent that they still consider gay acts as inadmissible.

Natural law has it that, homosexuality is against natural law, and is fundamentally sterile - homosexuality, by its very nature, is not open to procreation and upbringing of children. [13] Here for the sake of brevity we would like to prescind from the question of homosexuality and assisted human reproduction, with all the social and moral implications.

There are also many "gay rights" activists who clamour for the rights of homosexuals to adopt children. This is an interesting argument and it is also important to raise significant questions: if homosexuality were to become the socio-cultural norm, will it be possible for homosexuals to adopt children? Whose child are they going to adopt? Are homosexuals who want to adopt children also paying attention to the rights and the needs of the children? Do the children they have set out to adopt have the right to grow up in a family, with a mother and a father? Here, at least parenthetically it would be important to draw attention to the ethical challenge raised by the Kantian categorical imperative or fundamental principle of practical reason: "act only on that maxim through which you can at the same time will that it should become a universal law." [14]

The Congregation as highlighted above has had series of plenary gathering in an attempt to unravel the ministry behind homosexuality not forgetting the inputs made by the Congregation for the Divine Cult and Discipline of Sacraments, together with other congregations coupled with the Pontifical Council for Legislative texts.

The instruction asserts that the Church:

"Cannot admit in seminaries nor give access to the sacred Orders to those who practice homosexuality, who present deep-seated homosexual tendencies or supporting the so-called gay culture." [15]

When discussing about homosexuality (both in general and their place in the clergy) and in responding to the question of "gay lobby", Pope Francis has this to say;

"If someone is gay and is searching for the Lord and has good will, then who am I to judge him?

The Catechism of the Catholic Church explains this in a beautiful way, saying..: 'no one should marginalize these people for this, they must be integrated into the society". [16]

Thus, pastors of souls should as a matter of necessity "accompany them spiritually" without turning them away.

\subsection{CONCLUSION}

The questions of human sexuality, homosexuality, and gay rights, are serious questions, expressing themselves at diverse levels of complexities, we have not exhausted the profound nature of the complexities and neither have all the problems been resolved. It is a task that demands continuous intellectual engagement and further elucidation. Bearing in mind that homosexuality is a complex phenomenon. In an attempt to unravel its complexities and to strike a balance the Church maintains that, being gay is not inherently sinful as a person does not choose to be either homosexual or heterosexual. [17] Not losing sight that in the Catholic theology of sexuality, the church maintains that sexual act should and must symbolize the expression of male-female harmonious monism and as such open to fecundity, and sexual acts between parties of the same sex orientation cannot meet this demand. With this in mind, Homosexuality becomes sinful. Little wonder then did the Church maintain that gay people like others are called to practice chastity. [18]]

In the light of the relationship between the civil law and the moral law the call to responsibility demands that every human person, should be treated with the dignity and the respect that is due to the human person as transcendent subjectivity 
within the universe of intersubjective and inter-social relationships, which supersede the transhuman and the posthuman agenda. Little wonder did the Catechism of the Catholic Church maintains that gay people "must be accepted with respect, compassion, and sensitivity", and that "every sign of unjust discrimination in their regard should be avoided." [19]

Therefore, in the face of the multifaceted Bioethical and Bio-political challenges, this paper affirms as part of its conclusion that the human society has the responsibility to say no to every form of dehumanization and victimization of human persons, including persons with homosexual orientation.

The imperative of responsibility demands that the institution of marriage, as the bedrock of authentic human civilization should be treated with respect. The call for responsibility also demands that every human person, including persons with homosexual tendencies, should be treated with the dignity and the respect that is due to the human person as transcendent subjectivity within the universe of intersubjective and inter-social responsibilities, which transcends the transhuman and the posthuman agenda. [20]

Therefore, the human society has the responsibility of affirming the dignity, the grandeur and the beauty of the family, the bedrock of authentic human development. In the spirit of responsibility and in a collaborative framework, it is important for the family, and the entire human society to be dedicated to the care and education of the young in all aspects of human development in acknowledgement of the fact that the young embody the hope and the future aspirations of humanity as a whole.

\section{REFERENCES}

1) Beck, U., Giddens, A., and Lash, S. (1994) "Reflexive Modernization: Politics, Tradition and Aesthetics in the Modern Social Order", CA: Stanford University Press, Stanford.

2) https://Olga.org/downloads/2017/ILGA State Sponsored Homophobia, Retrieved 7th March 2021.

3) Lovelace, R. F. (1978) "Homosexual and the Church", Lamp Press, London, pp.29-33.

4) "Sexual Orientation and Homosexuality". www.apa.org.American Psychological Association. Retrieved 13 April 2021.

5) Rosario, M., Schrimshaw, E., Hunter, J., and Braun, L. (2006) "Sexual Identity Development among Lesbian, Gay and Bisexual Youths: Consistency and Change over time", Journal of Sex Research, 43(1): 46-58.

6) Coleman, E. (2004) "Homosexuality: Clinical and Behavioral Aspects", The Encyclopedia of Bioethics, 3rd edition, ed. Stephen G. P., Macmillan Reference USA, New York, p.1158.

7) Etim, M., (2021) "Bioethical and Bio-Political Challenges in relation to Human Sexuality and Question of Homosexuality", An Unpublished Talk.

8) Ibid.

9) Johnson S. M. and O'Connor, E. (2002) "The Gay Baby Boom: The Psychology of Gay Parenthood", New York University Press, New York.

10) Clark, A. (2012) "Desire: A History of European Sexuality, Routledge, pp.74-75.

11) Congregation for the Doctrine of the Faith, Persona Humana: Declaration on Certain Questions Concerning Sexual Ethics, no.1.

12) Letter to the Bishops of the Catholic Church on the Pastoral Care of Homosexual Persons (Homosexualitatisproblema) of Oct. 1, 1986, nose. 4 and 7.

13) Etim, M. Op.cit.

14) Kant, I., Kritik der Praktischen Vernunft "Handle so, da die Maxime deines Willens jederzeit zugleich als Prinzip einer allgemeinen Gesetzgebung gelten Kinney," V-30.

15) Pope Benedict XVI, on August 31, has approved this instruction and ordained its publication. This one has been signed on November 4th, 2005, on the memory of Saint Charles Borromeo, Saint Patron of seminaries, by his Eminence Cardinal Zenon Grocholewski, Prefect of the Congregation for Catholic Education, and his Excellency Msgr. Michael J. Miller CSB, its Secretary.

16) "Press Conference of Pope Francis during the return flight", Holy See, 28 July 2013. Retrieved 10 April, 2021.

17) Curran, C. E., Curran, C. A., and McCormick, R. A. (1998) "John Paul II and Moral Theology", Pauline Press, p.178.

18) Catechism of the Catholic Church, pp. 2357-2359.

19) Op.cit., pp. 2357-2358.

20) Etim, M., Op.cit 